\title{
Kedudukan Kreditur Terhadap Jaminan Atas Harta Bersama Yang Belum Dibagi Akibat Perceraian
}

\author{
Kadek Dian Rosita ${ }^{1}$ Putu Edgar Tanaya ${ }^{2}$
}

1Fakultas Hukum Universitas Udayana, E-mail: kadekdianrosita@gmail.com

2Fakultas Hukum Universitas Udayana, E-mail: edgar_tanaya@unud.ac.id

\section{Info Artikel \\ Masuk : 15 Desember 2020 \\ Diterima : 15 Desember 2020 \\ Terbit : 1 April 2020 \\ Keywords : \\ Joint Property, Guarantee, \\ Divorce \\ Kata kunci: \\ Harta Bersama, Jaminan, Cerai \\ Corresponding Author: Kadek Dian Rosita, E-mail: kadekdianrosita@gmail.com \\ DOI : \\ 10.24843/AC.2021.v06.i01.p07}

\begin{abstract}
The purpose of this study is to examine legal arrangements regarding joint assets that have not been shared due to divorce which used as the object of credit collateral and to provide legal certainty regarding the position of the bank as a creditor providing credit with collateral for joint assets which is used as the object of collateral. The method used in this research is normative legal research method. The results of the study show that (1) An agreement from one of the parties is required if you want to use joint assets, this is in accordance with the provisions of Article 36 paragraph (1) of the Marriage Law. (2) The provision of credit by the Bank is carried out on a prudent basis, and based on the $5 \mathrm{C}$ principle so that credit agreement products are not legally flawed and can be canceled by law. The legal consequence of the imposition of collateral for joint assets obtained during marriage without the consent of one of the parties for credit is that the guarantee agreement can be canceled (voidable/vermetig).
\end{abstract}

\section{Abstrak}

Tujuan dari Penelitian ini mengkaji pengaturan hukum mengenai harta bersama yang belum dibagi akibat adanya perceraian yang dijadikan objek jaminan kredit dan untuk memberikan kepastian hukum mengenai kedudukan bank sebagai kreditor yang memberikan kredit dengan jaminan harta bersama yang dijadikan sebagai objek jaminan. Metode yang digunakan dalam penelitian ini adalah metode penelitian hukum normatif. Hasil dari studi menunjukkan bahwa (1) Diperlukannya persetujuan dari salah satu pihak apabila ingin menggunakan harta bersama, hal tersebut sesuai dengan ketentuan Pasal 36 ayat (1) Undang-Undang Perkawinan. (2) Pemberian kredit oleh Pihak Bank dilaksanakan dengan prinsip kehati-hatian, dan berdasarkan prinsip 5C agar tidak terjadinya produk perjanjian kredit yang cacat hukum dan dapat dibatalkan demi hukum. Akibat hukum dari pembebanan jaminan atas harta bersama yang diperoleh selama melangsungkan perkawinan dengan tanpa adanya persetujuan dari salah satu pihak atas kredit adalah dapat dibatalkannya (voidable/ vermetig) perjanjian jaminan tersebut. 


\section{Pendahuluan}

Sebagai bagian dari pembangunan Negara, pembangunan ekonomi merupakan cara untuk mewujudkan kehidupan yang adil dan sejahtera sebagaimana telah ditentukan didalam Pancasila dan Undang-Undang Dasar Negara Republik Indonesia Tahun 1945. Pada Undang- Undang Nomor 39 Tahun 1999 tentang Hak Asasi Manusia(untuk selanjutnya disebut Undang- Undang HAM) didalam Pasal 36 menyatakan bahwa kesejahteraan didalam keluarga merupakan hal yang fundamental atau merupakan hak asasi. Sifat dasar manusia sebagai makhluk sosial adalah senang bergaul dan tidak pernah hidup seorang diri, berkumpul serta bersosialisasi dengan yang lainnya. Pada dasarnya, manusia terlahir untuk berpasangan, mempunyai kecenderungan untuk berkeluarga dan melahirkan keturunan melalui ikatan perkawinan. Didalam UndangUndang Nomor 16 Tahun 2019 Tentang Perubahan Atas Undang-Undang Nomor 1 Tahun 1974 Tentang Perkawinan (untuk selanjutnya disebut Undang-Undang Perkawinan) menyatakan "perkawinan adalah ikatan lahir bathin antara seorang pria dan seorang wanita sebagai suami istri dengan tujuan membentuk keluarga (rumah tangga) yang bahagia dan kekal berdasarkan Ketuhanan Yang Maha Esa". Apabila dilihat dari sudut pandang sosiologis, dapat diketahui perkawinan merupakan bentuk kerjasamaantara pria dan wanita didalam kehidupan bermasyarakat berdasarkan dengan peraturan khusus dan dalam hal ini berlandaskan oleh Negara, agama, adat istiadat yang berarti didalam peraturan-peraturan tersebut memiliki tujuan untuk mengumumkan status yang baru kepada orang lain atau masyarakat setempat bahwa pasangan ini agar diakui dan diterima statusnya sebagai pasangan yang sah secara adat maupun secara hukum sebagai suami istri.

Perkawinan adalah sah apabila dilakukan menurut hukum masing-masing agama dan kepercayaannya dan dicatat menurut peraturan perundang-undangan yang berlaku. Dalam UU Perkawinan dianut asas monogami yaitu suatu perkawinan antara seorang pria dan seorang wanita sebagai isteri dan seorang wanita hanya boleh mempunyai seorang suami. Akan tetapi UU Perkawinan itu juga memberikan kemungkinan seorang pria mempunyai lebih seorang istri (berpoligami). Perkawinan mempunyai akibat hukum yang tidak hanya terhadap diri pribadi mereka yang melangsungkan pernikahan, tetapi mempunyai akibat hukum terhadap harta suami istri tersebut. ${ }^{1}$

Persoalan mengenai harta didalam perkawinan merupakan suatu permasalahan yang cukup berpengaruh dalam kehidupan perkawinan, terutama didalam kasus perceraian. Oleh karenanya, Hukum Harta Perkawinan memiliki kedudukan yang penting didalam kehidupan berkeluarga bahkan pada saat perkawinan tersebut masih berlangsung dan harmonis. Pengaturan hukum mengenai harta benda didalam perkawinan telah diatur didalam Pasal 35 Undang-Undang Perkawinan. Hak milik pribadi adalah hak asasi pribadi, sedangkan hak milik bersama merupakan hak asasi yang mengatur tentang ruang lingkupnya, yang dimana untuk selanjutnya agar tidak terjadi konflik serta campur aduk diantara hak-hak tersebut. Dari penjelasan diatas, dapat kita ketahui, harta bersama ialah harta yang didapat pada saat melangsungkan perkawinan. Didalam Undang-Undang HAM disebutkan bahwa pasangan suami istri memiliki hak serta kewajiban yang sama atas harta yang didapatkan selama melangsungkan perkawinan demikian ternyata berdasarkan ketentuan Pasal 51 yang menyatakan bahwa: “(1)

\footnotetext{
1 Wijayanti, W. (2016). Kedudukan istri dalam pembagian harta bersama akibat putusnya perkawinan karena perceraian terkait kerahasiaan bank. Jurnal Konstitusi, 10(4), 709-730., h. 711
} 
Seseorang istri selama dalam ikatan perkawinan mempunyai hak dan tanggung jawab yang sama dengan suaminya atas semua hal yang berkenaan dengan kehidupan perkawinannya, hubungan dengan anak-anaknya, dan hak pemilikan serta pengelolaan harta bersama; (2) Setelah putusnya perkawinan, seseorang wanita mempunyai hak dan tanggung jawab yang sama baik mengenai harta bersama ataupun mengenai anakanaknya, dengan memperhatikan kepentingan terbaik bagi anak".

Hukum keluarga juga meliputi ketentuan mengenai kekayaan, sehingga dapat dikatakan bahwa Undang- Undang Perkawinan juga mengatur tentang hukum kekayaan. Subekti dengan tegas mengatakan, bahwa hukum keluarga juga meliputi hubungan hukum dalam lapangan hukum kekayaan antara suami istri. ${ }^{2}$

Untuk mengembangkan sebuah usaha, harta yang didapatkan selama melangsungkan perkawinan biasanya dapat digunakan sebagai modal, hal ini dikarenakan harta benda bersama bisa dijadikan sebagai jaminan dilembaga keuangan, baik itu lembaga perbankan maupun non perbankan. Bagi masyarakat, baik itu secara individu maupun badan usaha yang ingin memperluas dan menambah kebutuhan konsumtif dan produktif sangat membutuhkan dana yang disediakan oleh bank sebagai sumber dana, termasuk dalam bentuk kredit agar cukup untuk mendukung perkembangan usahanya. Melihat betapa besarnya pengaruh pengaruh dana kredit didalam proses pembangunan, maka sepantasnya para pemberi dan penerima kredit serta para pihak yang memiliki kepentingan didalamnya perlu memperoleh perlindungan hukum melalui suatu lembaga jaminan guna mendapatkan kepastian hukum untuk pihak-pihak yang berkepentingan dengan maksud meminimalisir resiko kreditur dimasa depan. Maka dari itu, untuk usaha tersebut, kita menggunakan jasa perbankan. Secara umum, Bank kerap berupaya untuk mengumpulkan dana masyarakat berbentuk simpanan, selanjutnya melalui dana tersebut dikelola yang nantinya akan disalurkan berupa pinjaman atau kredit kepada masyarakat. Oleh karenanya, untuk bisa menyalurkan pinjaman kepada masyarakat diharuskan dengan adanya kesepakatan atau perjanjian dengan bank selaku kreditor dengan calon nasabah debitur sebagai penerima yang dinamakan perjanjian kredit, dan dikarenakan dana yang disalurkan tersebut adalah dana milik masyarakat, maka dari itu proses penyalurannya harus dipertanggungjawabkan. Didalam pelaksanaannya, untuk lebih menciptakan rasa aman dalam penyaluran dana yang diberikan oleh kreditur kepada debitur diperlukan dengan memberikan pengamanan tambahan berupa jaminan khusus. Yang sering digunakan berupa jaminan kebendaan, yaitu benda bergerak ataupun benda tidak bergerak. Fasilitas kredit yang dimaksudkan adalah Hak Tanggungan maupun Fidusia. Yang merupakan pemindahtanganan atas hak kepemilikan berdasarkan kepercayaan terhadap suatu benda dengan ketentuan objek yang akan dialihkan, dan penguasaannya akan tetap menjadi pemilik dari benda tersebut. Untuk mendapatkan jaminan tersebut, benda bergerak yang dijadikan sebagai objek jaminan kredit harus didaftarkan ke Kantor Jaminan Fidusia yang ruang lingkup tugasnya merupakan bgian dari Kementerian Hukum dan Hak Asasi Manusia untuk memperoleh Sertipikat Jaminan Fidusia sebagai bukti yang menyatakan bahwa objek benda bergerak tersebut sudah menjadi jaminan kredit. Dan untuk benda tidak bergerak seperti tanah yang dijadikan sebagai objek jaminan harus didaftarkan ke Badan Pertanahan Nasional untuk diterbitkan Sertipikat Hak Tanggungan. Jika salah satu objek yang akan didaftarkan

${ }^{2}$ Anshary M. (2016). Harta Bersama Perkawinan Dan Permasalahannya. Bandung: CV Mandar Maju. h. 16 
kepada Kantor Pendaftaran Fidusia terdapat permasalahan harta gono-gini yang belum dibaginya kepada mantan istri kreditur yang disebabkan putus karena perceraian terhadap kendaraan tersebut, maka dapat dikatakan perjanjian tersebut dapat dibatalkan, sehingga tidak ada kepastian hukum bagi penerima Jaminan tersebut. ${ }^{3}$

Mengenai harta yang didapatkan selama melangsungkan perkawinan, suami dan istri berhak menggunakannya berdasarkan persetujuan dan kesepakatan para pihak. Apabila suami istri didalam pernikahannya membawa harta bawaan, penggunaan sepenuhnya berada ditangan masing-masing pihak. Apabila terjadi perceraian, baik suami maupun istri dapat menggugat harta yang mereka dapat selama melangsungkan perkawinan. Namun apakah yang akan terjadi apabila harta bersama selama perkawinan belum dibagi sesudah adanya putusan perceraian digunakan sebagai jaminan kredit disebuah lembaga penjaminan.

Dalam hal ini untuk lebih jelasnya, penulis memberikan sebuah contoh kasus Putusan Nomor 63/Pdt.G/2013/PN.Gs, yang terjadi di Kabupaten Gresik. Hal tersebut terjadi dalam perkara antara Idatul Ifa melawan Zainul Arifin. Didalam perkara ini, penggugat adalah istri, mengajukan gugatan kepada mantan suami atas harta bersama yang diperoleh selama melangsungkan perkawinan, kemudian dijadikan sebagai objek jaminan agunan kredit di Lembaga Penjaminan atau Bank sampai akhirnya terjadi wanprestasi karena ketidaksanggupan membayar. Namun, didalam kasus ini lebih menekankan mengenai penggunaan atas harta bersama yang diperoleh selama melangsungkan perkawinan yang belum dibagi akibat perceraian digunakan sebagai objek jaminan kredit di PT. Bank Danamon Indonesia cabang Gresik yang berakibat macetnya kredit serta terjadi pelaksanaan lelang dan dimenangkan oleh $\mathrm{H}$. Soelikin. Dari latarbelakang yang diuraikan diatas, maka penulis tertarik untuk lebih dalam membahasnya dalam bentuk jurnal ilmiah yang berjudul "Kedudukan Hukum Kreditur Terhadap Objek Jaminan Atas Harta Bersama Yang Belum Dibagi Akibat Perceraian".

Berdasarkan uraian diatas, tulisan ini hendak membahas mengenai (1) Pengaturan hukum harta bersama yang belum dibagi karena perceraian yang dijadikan sebagai objek jaminan kredit (studi kasus Putusan Nomor 63/Pdt.G/2013.Gs) dan (2) Kedudukan hukum kreditur terhadap objek yang dijadikan jaminan atas harta bersama yang belum dibagi akibat perceraian (studi kasus Putusan Nomor 63/Pdt.G/2013/PN.Gs).

Tujuan dari penelitian ini mengkaji pengaturan hukum mengenai harta bersama yang belum dibagi akibat adanya perceraian yang dijadikan objek jaminan kredit dan untuk memberikan kepastian hukum mengenai kedudukan bank sebagai kreditor yang memberikan kredit dengan jaminan harta bersama yang dijadikan sebagai objek jaminan.

Dalam tulisan artikel ilmiah ini menggunakan 2 (dua) tulisan terdahulu untuk menjadi perbandingan, yang diantaranya : 1. Jurnal yang ditulis oleh Astriani Van Bone yang diterbitkan oleh Fakultas Hukum Universitas Samratulangi. Judul Penyelesaian Harta Bersama Berstatus Agunan Dalam Perkara Perceraian di Pengadilan Negeri. Permasalahan yang diangkat yakni (1) Bagaimana Proses penyelesaian sengketa harta bersama yang objek sengketanya masih diagunkan sebagai agunan dalam perkara

\footnotetext{
${ }^{3}$ Riyanto, F. S. (2019). KEDUDUKAN KREDITUR ATAS OBJEK JAMINAN FIDUSIA YANG BELUM DIBAGI KARENA ADANYA PERCERAIAN. JURNAL RECHTENS, 8(1), h. 38.
} 
perceraian dijalankan di Pengadilan Negeri? (2) Bagaimana pertimbangan Hakim dalam memberikan putusan perkara penyelesaian sengketa harta bersama dalam perkara perceraian di Pengadilan Negeri?4. 2. Jurnal yang ditulis oleh Kadek Setyawan Danarta yang diterbitkan oleh Program Pascasarjana Universitas Sunan Giri Surabaya. Judul Karakteristik Pemasangan Hak Tanggungan Terhadap Harta Perkawinan. Permasalahan yang diangkat (1) Kedudukan hukum harta perkawinan dalam sebuah rumah tangga jika dijadikan hak tanggungan dan (2) pelaksanaan pemasangan hak tanggungan terhadap harta perkawinan. ${ }^{5}$

Penelitian ini memiliki fokus bahasan yang berbeda dengan tulisan sebelumnya, dimana kebaharuannya terletak pada pembahasannya yang membahas mengenai harta bersama yang belum dibagi akibat adanya perceraian yang dijadikan objek jaminan kredit serta bagaimana implementasi peraturannya yang dijadikan dasar didalam putusan pengadilan.

\section{Metode Penelitian}

Penelitian hukum ini menggunakan penelitian hukum normatif, dimana meneliti hukum dari perspektif internal dengan objek penelitiannya adalah norma hukum. ${ }^{6}$ Penelitian ini berawal dari adanya konflik norma terkait penggunaan harta bersama yang diperoleh selama melangsungkan perkawinan yang harus didasarkan persetujuan salah satu pihak sebagaimana telah ditentukan didalam Undang-Undang Perkawinan didalam Pasal 36 ayat (1) Pasal 36 ayat (1), namun apabila melihat prakteknya terjadi penggunaan harta bersama tanpa persetujuan salah satu pihak. Metode pendekatan yang digunakan adalah metode pendekatan kasus (the case approach). Penelitian ini menggunakan peraturan perundang-undangan sebagai bahan hokum primer, buku, literatur serta dokumen yang kredit perbankan serta mengenai harta bersama didalam hukum keluarga. Penulisan jurnal ilmiah ini menggunakan teknik penelusuran bahan hukum studi dokumen, dan analisis kajian yang menggunakan teknik analisis kualitatif. Adanya analisa kasus didasarkan atas pemikiran dari penulis bahwa dalam prakteknya tidak berlajalan sesuai dengan ketentuang perundang-undangan. Kasus yang dikasi adalah Kasus Putusan Nomor 63/Pdt.G/2013/PN.Gs.

\section{Hasil dan Pembahasan}

\subsection{Pengaturan Hukum Mengenai Harta Bersama Yang Belum Dibagi Karena Perceraian Sebagai Objek Jaminan Kredit (Studi Kasus Putusan Nomor 61/Pdt.G/2013/PN.Gs)}

Pasal 1 Undang-Undang Perkawinan menjelaskan perkawinan adalah "ikatan lahir bathin antara seorang pria dengan seorang wanita sebagai suami isteri dengan tujuan membentuk keluarga (rumah tangga) yang bahagia dan kekal berdasarkan Ketuhanan Yang Maha Esa". Serta pengertian berdasarkan Kompilasi Hukum Islam didalam Pasal

\footnotetext{
${ }^{4}$ Van Bone, A. (2017). Penyelesaian Sengketa Harta Bersama Berstatus Agunan dalam Perkara Perceraian di Pengadilan Negeri. Lex Administratum, 5(5). h. 81.

${ }^{5}$ Danarta, K. S. (2019). Karakteristik Pemasangan Hak Tanggungan Terhadap Harta

Perkawinan. Jurnal Media Hukum dan Peradilan, 161-174. h. 163.

${ }^{6}$ Diantha, I. M. P. (2016). Metodologi Penelitian Hukum Normatif dalam Justifikasi Teori Hukum. Jakarta: Prenada Media. h. 12.
} 
2 adalah "pernikahan, yaitu akad yang sangat kuat atau mitsaqan ghalizhan untuk mentaati perintah Allah dan melaksanakannya merupakan ibadah".

Sesuai dengan pengertian perkawinan diatas, jika kita simpulkan perkawinan ialah suatu perbuatan hukum yang akan menimbulkan hak dan kewajiban diantara pihakpihak yang akan melangsungkan perkawinan tersebut. Hak dan kewajiban yang ditimbulkan didalam perkawinan tersebut harus dipenuhi oleh pihak-pihak yang terkait. Tidak hanya menimbulkan hubungan kekeluargaan, akibat hukum lain yang timbul adalah didalam bidang harta kekayaan. Permasalahan mengenai harta kekayaan didalam perkawinan adalah hal yng menarik untuk dibahas dan ditinjau lebih dalam, menginat sebelum melangsungkan perkawinan, para pihak membawa harta bawaannya sendiri dan selama perkawinan berlangsung suami istri suami istri mendapatkan harta kekayaan perkawinan secara sendiri ataupun bersama-sama. ${ }^{7}$ Ruang lingkup perkawinan cukup luas seperti ruang lingkup sosial dan ruang lingkup hukum, yaitu dimulainya padaa saat perkawinan, perkawinan berlangsung dn setelah perkawinan, hal ini dikarenakan adanya kemungkinan yang akan terjadi didalam perkawinan tersebut, seperti ; permasalahan mengenai harta benda, permasalahan mengenai keturunan, serta bilamana tidak adanya ketentuan atau kesepatakan bersama mengenai permasalahan pembagian harta peninggalan dari salah satu pihak yang meninggal ataupun perceraian, termasuk juga perihal harta bawaan dari para pihak serta harta bersama yang didapat selama melangsungkan perkawinan. Didalam sistem perkawinan masyarakat biasanya telah mengenal istilah sistem pencampuran harta selama melangsungkan perkawinan dan para pengantin tidak akan mempermasalahkan tentang harta tersebut. Adanya pemahaman mengenai asas kepercayaan antar pasangan inilah yang menjadi dasar dalam penyatuan harta perkawinan ini. ${ }^{8}$

Mengenai harta kekayaan didalam perkawinan pada dasarnya ada 2 (dua), yakni harta bawaan dan harta bersama. Harta yang dibawa oleh suami dan istri kedalam perkawinan merupakan harta bawaan. Dan harta bersama ialah harta yangdidapatkan semasa melangsungkan perkawinan. Ruang lingkup harta bersama secara umum mencangkup ; harta yang dibawa masing-masing pihak, segala pengahasilan pribadi suami dan istri, harta yang dibeli selama melangsungkan perkawinan, harta yang dibeli dan dibangun, harta yang dapat dibuktikan, serta harta yang didapatkan selama perkawinan berlangsung. Hal ini berdasarkan dengan ketentuan didalam Pasal 35 Undang-Undang Perkawinan yaitu "Harta benda yang diperoleh selama perkawinan menjadi harta bersama, dan harta bawaan dari masing-masing suami dan istri dan harta benda yang diperoleh masing-masing sebagai hadiah atau warisan adalah dibawah penguasaan masing-masing sepanjang para pihak tidak menentukan lain". Pengaturan mengenai harta bersama telah diatur didalam Pasal 36 yaitu "mengenai harta bersama, suami dan istri dapat bertindak atas persetujuan kedua belah pihak, dan harta bawaan masing-masing suami dan istri mempunyai hak sepenuhnya untuk melakukan perbuatan hukum mengenai harta bendanya". Dan juga mengenai perceraian telah diatur didalam Pasal 37 yang menyebutkan "Bila perkawinan putus karena perceraian harta bersama diatur menurut hukumnya masing-masing". Berdasarkan ketentuanketentuan diatas, perihal harta bersama yang didapat sewaktu melangsungkan

\footnotetext{
7 Van Bone, A., op.cit, h. 80

8 Pratama, A. (2018). Implementasi Percampuran Harta Bersama Dan Harta Bawaan Dalam Perkawinan (Studi Kasus Putusan Pengadilan Agama Nomor: 0189/Pdt. g/2017/Pa. Smg). Jurnal Ius Constituendum, 3(1), hal. 17
} 
perkawinan nantinya akan dibagi apabila perkawinan tersebut putus, dapat dikarenakan kematian, perceraian ataupun putusan pengadilan. Harta bersama didalam perkawinan secara konsep telah dituangkan secara tegas didalam Pasal 119 KUHPerdata yaitu "Mulai saat perkawinan dilangsungkan demi hukum berlakuan persatuan bulan antara harta kekayaan suami dan istri, sekadar mengenai itu dengan perjanjian kawin tidak diadakan ketentuan lain. Persatuan ini sepanjang perkawinan tak boleh ditiadakan atau diubah dengan sesuatu persetujuan antara suami dan istri". Konsep dasar inilah yang terdapat didalam KUHPerdata yang bersumber dari Hukum Barat mengenai harta benda bersama yang secara mutlak adalah penyatuan antara harta yang diperoleh ataupun dibawa oleh suami dan istri selama melangsungkan perkawinan. Hal demikian dapat terjadi jika tidak ditentukan didalam perjanjian kawin, yang dimana merupakan satu-satunya bukti yang menyatakan tentang adanya harta didalam suatu perkawinan perihal pengurusannya dilakukan oleh pihak suami. Hak material yang dimiliki oleh suami inilah alasan sebagai suami untuk mengurus dan memelihara semua harta kekayaan didalam perkawinan yang nantinya akan berlangsung hingga putusnya perkawinan tersebut putus, kecuali telah ditentukan lain didalam perkanjian kawin. ${ }^{9}$ Dilakukannya penetapan terhadap harta bersama didalam sebuah perkawinan masih berlangsung dan melakukan pembagian atas harta bersama apabila putusannya perkawinan terjadi. Didalam Undang-Undang Perkawinan tidak menyebutkan mengenai asal harta tersebut, sehingga yang dapat dikatakan termasuk didalam harta bersama yaitu: (a)Hasil dari pendapatan suamiselama melangsungkan perkawinan;(b)Hasil dari pendapatanistri selama melangsungkan perkawinan; dan (c)Hasil dari pendapatn harta bawaan suami dan atau istri, meskipun itu merupakan harta pokoknya tidak termasuk didalam harta bersama asalkan semuanya didapat sewaktu perkawinaan masih berlangsung. ${ }^{10}$

Namun, apabila kita melihat didalam ketetuan Pasal 124 KUHPerdata, mengenai harta yang didapat selama melangsungkan perkawinan, suami memiliki hak untuk mengurus harta bersama, didalam hal ini termasuk dengan wewenang untuk melakuka berbagai perbuatan terhadap harta bersama. Ketentuan tersebut adalah :

(1) Hanya suami saja yang boleh mengurus harta bersama itu ;

(2) Dia boleh menjualnya, memindahtangankan dan membebaninya tanpa bantuan istrinya, kecuali dalam hal yang diatur dalam Pasal 140;

(3) Dia tidak boleh memberikan harta bersama sebagai hibah antara mereka yang sama-sama masih hidup, baik barang-barang tak bergerak maupun keseluruhannya atau suatu bagian atau jumlah yang tertentu dan barangbarang bergerak, bila bukan kepada anak-anak yang lahir dari perkawinan mereka, untuk member suatu kedudukan;

(4) Bahkan dia tidak boleh menetapkan ketentuan dengan cara hibah mengenai suatu barang yang khusus, bila dia memperuntukkan suatu dirinya hak pakai hasil dari barang itu.

9 Subagia, N. K. T. F., \& Rudy, D. G. PENGARUH KEPAILITAN TERHADAP HARTA BERSAMA SUAMI ISTRI DITINJAU DARI PERSPEKTIF. Kertha Wicara: Journal Ilmu Hukum, hal. 3.

10 Sugiswati, B. (2014). Konsepsi Harta Bersama Dari Perspektif Hukum Islam, Kitab UndangUndang Hukum Perdata Dan Hukum Adat. Perspektif, 19(3), 201-211., hal. 203 
Dari Pasal diatas, kita ketahui bahwa suamii memiliki kewenangan untuk mangatur, mengurus dan melakukan perbuatan atas harta kekayaan didalam perkawinan dan istri tidak diperbolehkan turut serta didalam pengelolaan harta kekayaan tersebut. Namun, hal sebaliknya tentang pengecualian suami yang tidak diperbolehkn mengurus harta kekayaan sendiri telah diatur didalam Pasal 140 ayat (3) KUHPerdata yakni "mereka juga berhak untuk membuat perjanjian, bahwa meskipun ada golongan harta bersama, barang-barang tetap, surat-surat pendaftaran dalam buku besar pinjaman-pinjaman Negara, surat-surat berharga lainnya dan piutang-piutang yang diperoleh atas nama istri, atau yang selama perkawinan dan pihak istri jatuh kedalam harta bersama, tidak boleh dipindah tangankan atau dibebani oleh suami tanpa persetujuan istri."

Putusnya suatu perkawinan biasanya disebabkan oleh adanya kematian, perceraian, serta berdasarkan putusan pengadilan. Putusnya perkawinan dikarenakan perceraian pada umumnya dikarenakan adanya perbuatan zina, salah satu pihak pemabuk, pemadat, penjudi, meninggalkan kawan kawinnya selama 2(dua)tahun berturut-turut, dijatuhi hukuman penjara selama 5(lima) tahun atau lebih, adanya perselisihan serta adanya pertengkaran didalam perkawinan tersebut. Sebelum melakukan perceraian, pengadilan akan memberikan kesempatan untuk melakukan mediasi antar pasangan suami istri tersebut dan apabila tidak berhasil mendamaikan kedua belah phak maka proses perceraian akan dilnjutkan dan hanya dapat dilakukan didepan sidang Pengadilan. Terjadinya perceraian mengakibatkan putusnya ikatan suami dan istri, putusnya hubungan hukum kekeluargaan, serta putusnya hubungan hukum harta kekayaan. Didalam hal ini hukum kekeluargaan menentukan hubungan hukum kekayaan dengan hukum kekayaan perkawinan yang tidak lain adalah hukum kekayaan keluarga.

Harta bersama umumnya dibagi dua sama rata di antara suami dan istri. Hal ini didasarkan pada ketentuan Pasal 128 KUHPerdata. Pembagian harta bersama bagusnya dilakukan secara adil, sehingga tidak menimbulkan ketidakadilan antara mana yang merupakan hak suami dan mana hak istri. Pembagian harta bersama dalam perkawinan perlu didasarkan pada aspek keadilan untuk semua pihak yang terkait keadilan yangdimaksud mencakup pada pengertian bahwa pembagian tersebut tidak mendiskriminasikan salah satu pihak. Kepentingan masing-masing pihak perlu diakomodasi asalkan sesuai dengan kenyataan yang sesungguhnya. ${ }^{11}$

Dipenulisan artikel ilmiah ini, penulis memberikan sebuah contoh kasus yang diambil dari situs resmi Direktori Putusan Mahkamah Agung Republik Indonesia khususnya didalam Putusan Sidang Pengadilan Negeri dengan Nomor Putusan 63/Pdt.G/2013/PN.Gs, dimana dalam perkara ini Tergugat atas nama Zainul Arifin (untuk selanjutnya disebut mantan suami) menggugat cerai Penggugat atas nama Idatul Ifa (untuk selanjutnua disebut mantan istri) di Pengadilan Agama Gresik hingga akhirnya pada tanggal 22 Nopember 2006 keluarlah Putusan Cerai antara mantan suami dan mantan istri yang selanjutnya pada tanggal 20 Desember 2006, Pengadilan Agama Gresik mengeluarkan Akta Cerai Nomor 845/AC/2006/PA.GS. Dari perceraian tersebut adapun fakta objek dari harta bersama adalah tercatat atas nama mantan suami, hal ini tidak mengurangi hak mantan istri, karena objek sengketa faktanya diperoleh dalam

11 Waha, F. M. (2013). Penyelesaian Sengketa atas Harta Perkawinan setelah Bercerai. Lex et Societatis, 1(1)., h. 60 
masa mantan istri dan mantan suami masih dalam status perkawinan yang sah (berstatus suami istri). Objek dari harta bersama tersebut berupa sebidang tanahdan bangunan, dengan Sertipikat Hak Milik Nomor 481 dengan Surat Ukur Nomor 52/08.13/2001 tertanggal 17 Oktober 2001 seluas 200m2 tercatat atas nama Zainul Arifin. Dari uraian diatas, Majelis Hakim berpendapat bahwa telah terbukti mantan istri dan mantan suami mempunyai harta bersama. Bahwa meskipun mantan suami pada saat menjaminkan objek sengketa kepada pihak Bank dalam status telah bercerai, namun oleh karena tidak ada satupun fakta bahwa harta bersama telah dibagi dan masih menjadi satu kesatuan utuh objek sengketa, maka status objek sengketa yang dijaminkan kepada pihak Bank tersebut masih merupakan harta bersama antara mantan istri dengan mantan suami. Hal ini dikarenakan sebelum terjadinya pembagian terhadap harta bersama (gono gini) maka status kepemilikan atas objek sengketa tetap sebagai harta bersama meskipun telah bercerai. Didalam kasus tersebut, dari fakta persidangan perkawinan antara mantan suami dan mantan istri, Majelis Hakim tidak menemukan fakta adanya perjanjian pernikahan antara mantan suami dan mantan istri. Akibat hukum dari tidak adanya perjanjian pemisahan harta ini, maka sejak dimulainya perkawinan antara mantan suami dengan mantan istri telah terjadi percampuran harta kekayaan (algehele gemeenchap van goederen), yang seterusnya akan berlaku dan tidak bisa diubah selama melangsungkan perkawinan. Atau dengan kata lain, terjadinya percampuran harta kekayaan mengenai seluruh kegiatan aktiva dan pasiva yangdibawa oleh saumi istri kedalam perkawinanataupun kemudian hari didapatkan didalam melangsungkan perkawinan merupakan harta bersama. Dengan demikian, karena telah terbukti antara mantan istri dan mantan suami merupakan pasangan kawin yang tidak memakai perjanjian perkawinan selama melangsungkan perkawinan, maka dari itu seluruh harta yang didapat selama melangsungkan perkawinan adalah harta bersama bersama dari mantan suami dan mantan istri, yang bilamana dikemudian hari akan melakukan suatu tindakan hukum atas harta bersama tersebut, sepatutnya didasari atas persetujuan dari salah satu pihak istri maupun pihak suami.

\subsection{Kedudukan Hukum Kreditur Terhadap Objek Jaminan Atas Harta Bersama Yang belum Dibagi Akibat Adanya Perceraian (Studi Kasus Putusan Nomor : 63/Pdt.G/2013/PN.Gs)}

Sejak menggunakan uang sebagai metode pebayaran, kegiatan pinjam meminjam uang juga termasuk didalamnya. Dalam rangka mendukung perkembangan ekonomi serta meningkatkan taraf hidup manusia, maka hampir seluruh lapisan masyarakat memandang bahwa kegiatan pinjam meminjam uang merupakan hal yang sangat dibutuhkan. Pihak yang memiliki dana lebih akan berperan sebagai pemberi pinjaman kepada mereka yang membutuhkan sesuai dengan kebutuhan atau tujuan tertentu. Oleh karenanya untuk memenuhi kebutuhan dana untuk menunjang kegiatan perekonomian dengan memberikan pinjaman dana berbagai lembaga keuangan khususnya bank dalam bentuk kredit perbankan. Kredit perbankan adalah layanan perbankan yang digunakan oleh masyarakat apabila membutuhkan dana. Dimana seseorang untuk mendapatkan modal, dapat berhubungan dengan pihak Bank dan dari hubungan tersebut akan timbul suatu perjanjian kredit. Perjanjian kredit merupakan suatu perjanjian pendahuluan (voorovereenkomst) dari penyerahan uang. Maksdunya adalah adanya hasil dari kesepakatan mengenai hubungan hukum diantara pemberi pinjaman dan penerima pinjaman. Perjanjian kredit bank bersifat konsensula (pacta de contrahendo) obligator yang berlandaskan Kitab Undang-Undang Hukum Perdata dan Undang-Undang 
Perbankan. Bentuk penyerahaannya dilakukan secara nyata (riil). Setelah melakukan penyerahan uang, maka hal-hal yang telah dituangkan kedalam perjanjian kredit pada kedua belah pihak barulah berlaku. Didalam prakteknya, untuk lebih menjamin dana dan memberukan rasa aman atas dana yang diberikan oleh kreditur kepada debitur diperlukan memberikan jaminan tambahan. Dalam hal ini jaminan tambahan yang dimaksud adalah berupa jaminan khusus, yang lazim digunakan ialah jaminan kebendaan yaitu benda bergerak dan benda tidak bergerak.

Didalam pemberian kredit, pihak bank benar- benar memperhatikan dalam setiap pengeluaran kredit pada debiturnya. Kemampuan debitur perihal bagaimana melunasi kredit nantinya merupakan hal yang perlu diperhatikan dan menjadi dasar pertimbangan pihak Bank dalam pemberian kredit. Dasar pemberian kredit dengan adanya kesepakatan antara Bank selaku kreditor dengan pihak yang lainnya yang mewajibkan debitur agar melunasi hutangnya sesuai dengan jangka waktu yang telah ditentukan ditambah dengan bunga maupun prestasi dan kontra prestasinya.

Bank dalam menyalurkan pinjaman berupa kredit mempunyai tingkat risiko yang sangat tinggi, sehingga sudah selayaknya bertindak ekstra hati-hati dan obyektif didalam menyetujui atau menolak permohonan pengajuan kredit oleh pihak debitur sehingga tidak berpotensi menimbulkan kerugian bagi pihak bank dikemudian hari. ${ }^{12}$

Dengan ditetapkannya ketentuan dan syarat- syarat oleh bank, pengembalian kredit dengan plafondering yang cukup tinggi tentu terasa berat. Untuk mengatasi kesulitan tersebut, terutama dalam penyediaan jaminan diberlakukan sistem pemberian jaminan oleh kreditur, dimana kreditur memberikan pengakuan tertulis yang berisikan bahwa debitur bersedia mengikatkan dirinya kepada kreditur selaku penerima jaminan mengenai jangka waktu dan syarat serta kondisi tertentu jika debitur penjamin tidak melaksanakan kewajibannyadikemudian hari. Didalam pemberian kredit, pada dasarnya terdapat 2 (dua) prinsip dasar, yang diantaranya:

a. Prinsip Kepercayaan : adalah proses Bank didalam pemberian kredit kepada calon nasabah debitur didasarkan atas dasar asas kepercayaan. Bank berkeyakinan kredit yang akan diberikan nanti akan memiliki manfaat untuk nasabah debitur sesuai dengan keperluannya. Serta Bank percaya bahwa debitur akan sanggup melunasi hutang kredit tersebut termasuk dengan bunganya didalam jangka waktu yang telah ditentukan.

b. Prinsip Kehati-hatian : dalam hal ini Bank wajib berpedoman dan melaksanakan prinsip kehati-hatian didalam melakukan kegiatan tersebut termasuk didalam memberikan kredit. Didalam penerapan prinsip ini harus konsisten berlandaskan itikad baik atas syarat-syarat beserta peraturan perundang-undangan yang berkaitan dengan pemberian kredit.

Kepercayaan merupakan unsur penting dalam penyaluran kredit, pemberian kredit haruslah didasarkan atas keyakinan dari kreditor bahwa dana yang disalurkan akan sanggup dikembalikan oleh debitor sesuai kesepakatan tenggang waktu yang ditentukan dalam perjanjian, oleh karenanya dalam menyalurkan kredit bank selaku kreditor juga harus memperhatikan asas-asas perkreditan dimana untuk dapat meningkatkan kepercayaan kepada debitor maka bank harus bias melakukan penilaian

12 Hartanto. J. A. (2015). Hukum Jaminan dan Kepailitan. Surabaya: Laksbang Justitia. h.13. 
terhadap calon debitor, adapun dalam penyaluran kredit dikenal asas 5C atau yakni hal hal dasar yang harus menjadi pokok bank ketika hendak menyalurkan kredit. ${ }^{13}$ Yang diantaranya adalah :

1). Character : pihak bank selaku calon kreditur akan melihat dan menilai bagaimana karakter serta latarbelakang calon nasabah debitur. Dari penilaian katakter Bank akan mengetahui tingkat integritas, kemauan serta kejujuran didalam menjalankan kewajiban serta bagaimana calon nasabah debitur menjalankan usahanya.

2). Capacity : pihak bank akan melihat bagaimana kemampuan dari calon nasabah debitur didalam mengelola usahanya dan melihat prospektif kedepannya, sehingga didalam mengambil pinjaman dan melunasi pinjaman sesuai dengan jangka waktu yang telah disepakati.

3). Capital : yaitu melihat kondisi asset serta kekayaan yang dimiliki calon nasabah debitur. Dari penelitian tersebut, calon kreditur akan menentukan layak atau tidaknya calon nasabah debitur untuk mendapatkan pinjaman serta besaran kredit yang akan diberikan nantinya.

4). Collateral : perlunya jaminan untuk menyetujui pembayaran kredit sebagai sarana pengamanan (back up). Prinsip ini perlu diperhatikan bagi calon kreditur apabila calon nasabah debitur tidak dapat memenuhi kewajibannya dikemudian hari (wanprestasi) maka pihak calon kreditur dapat menyita, menjual jaminan tersebut sebagai pelunasan kredit.

5). Condition of economy : berhubungan dengan perekonomian calon nasabah debitur dimasa depan. Dan kreditur dalam pemberian kredit harus diseuaikan untuk meminimalisir resiko yang nantinya akan muncul.

Diperlukan persetujuan dari pihak suami maupun istri untuk melakukan perjanjian kredit. Persetujuan suami istri dimaksudkan untuk memberikan jaminan kepada bank atau kreditur bahwa tidak akan ada sanggahan atau tuntutan dari suami atau istri terhadap Akta Pembuatan Hak Tanggungan (APHT) di waktu yang akan datang. Suami atau istri tersebut walaupun cakap, pada asasnya yang berhak menjaminkan bendanya adalah pemilik benda (orang yang berwenang untuk bertindak karena perbuatan menjaminkan sebagai langkah awal dari pengasingan benda tersebut). Hal ini sesuai dengan asas Nemo Plus Juris Transferre Potest Quam Ipse Habet bahwa tak seorangpun dapat mengalihkan lebih banyak haknya daripada yang ia miliki atau orang yang melakukan perbuatan hukum harus seuai dengan kewenangannya. ${ }^{14}$

Dalam pemberian kredit, Bank biasanya meminta jaminan secara khusus kepada calon nasabah debitur dengan adanya perjanjian jaminan baik berupa perjanjian perorangan ataupun perjanjian kebendaan. Para kreditur lebih menyukai perjanjian kebendaan daripada perjanjian perorangan, ini dikarenakan didalam perjanjian kebendaan lebih jelas menentukan mengenai benda-benda yang akan diikat dalam perjanjian tersebut serta objek benda jaminan telah disediakan untuk mencegah apabila nantinya terjadi kredit macet dan jaminan tersebut dapat digunakan sebagai sarana pelunasan hutang. ${ }^{15}$ Tujuan dari jaminan tersebut adalah mengcover hutang, memberikan kepastian hukum dan sebagai sarana perlindungan bagi kreditor untuk menjamin pelunasan hutang

\footnotetext{
${ }^{13}$ Gazali. D. S. \& Usman Rachmadi. (2012). Hukum Perbankan. Jakarta: Sinar Grafika. h. 263

${ }^{14}$ Usanti, Trisadini Prasastinah \& Bakarbessy Leonora. (2014). Hukum Jaminan. Surabaya: Revka Petra Media. h. 59.

${ }^{15}$ Danarta, K.S, op.cit, h. 162
} 
kredit, pelaksanaan prestasi seperti yang telah dituangkan didalam perjanjian kredit oleh calon nasabah debitur maupun penjamin debitur atau pihak ketiga. ${ }^{16}$ Dengan berkembangnya sektor ekonomi khususnya pada sektor sektor industri, perdagangan, perseroan, pengangkutan dan sektor lainnya, hukum jaminan senantiasa berkaitan dengan hukum ekonomi.

Hak dan kewajiban akan segera muncul, apabila kreditur dan calon nasabah debitur telah mencapai kesepakatan atas hasil dari perikatakan yang akan dijalin. Pihak-pihak diharuskan untuk memenuhi kewajibannya supaya perikatan tersebut dapat berlangsung sesuai dengan apa yang telah diharapkan dan diperjanjikan. Apabila ada salah satu pihak tidak melakukan sesuatu yang menjadi kewajibannya, maka pihak lainnya akan mengalami kerugian. Apabila ini terjadi, kreditur memiliki kewenangan utnuk menuntut pemenuhan kewajiban tersebut kepada debitur, jika diperlukan dapat memintabantuan hukum untuk melakukan daya paksa. Akan tetapi, bukan berarti daya paksa hukum tersebut lebih menekankan dengan kekerasan secara fisik kepada calon nasabah debitur untuk melakukan kewajibannya. Artinya, tidak dapat dilakukan paksaan yang secara langsung. ${ }^{17}$ Setiap kreditur memiliki kdudukan yang sama dengan kreditor lainnya, tidak ada kreditor yang diistimewakan ataupun dikhususkan dengan kreditor lainnya. Dalam pelaksanaan pelunasan atas hutang kreditnya pun dibagi secara "seimbang" berdasarkan besarnya jmlah yang terhutang oleh tiap-tiap kreditur dibandingkan dengan jmlah kesluruhan yang terhutang oleh debitur. Didalam Pasal 1132 KUHPerdata secara tegas telah diatur, yang menyebutkan "kebendaan tersebut menjadi jaminan bersama- sama bagi semua orang yang mengutangkan padanya, hasil penjualan benda- benda itu dibagi- bagi menurut keseimbangan, yaitu menurut besar kecilnya piutang masing- masing kecuali apabila diantara para berpiutang itu ada alasan yang sah untuk didahulukan". Adapaun kreditur yang diutamakan harus berdasarkan ketentuan didalam Pasal113 KUHPerdata yaitu "mereka yang memiliki hak- hak yang dilahirkan karena piutang yang diistimewakan (privilege ), dari gadai( pand ) dan dari hipotik". Dapat diketahui bahwa dalam hal ini kedudukan kreditur dientukan berdasarkan jenis jaminan yang dipegangnya. ${ }^{18}$

Didalam kasus Putusan Nomor 63/Pdt.G/2013/PN.Gs tersebut perbuatan mantan suami yang menjaminkan harta bersama yang belum dibagi (objek sengketa) kepada Bank Danamon (untuk selanjutnya disebut Bank) yakni dengan cara tanpa seijin atau persetujuan dari mantan istrinya, merupakan perbuatan wanprestasi karena perbuatannya tersebut bertentangan dengan hukum yang terjadi cacat dalam kesepakatan. Perjanjian kredit yang dilakukan sudah jelas tidak sah hal ini dikarenakan secara nyata telah dilarang dan telah diatur didalam Undang-Undang. Pasal 16 ayat (1) Undang- Undang Perkawinan menentukan bahwa "Mengenai harta bersama, suami atau isteri dapat bertindak atas persetujuan kedua belah pihak". Bahwa faktanya pula, Bank, selaku Kreditur, menyepakati dengan meniadakan dan tidak melaksanakan survei, klarifikasi dan verifikasi atas hak kepemilikan tanah dan bangunan sebagai jaminan tersebut, sehingga menurut keterangan mantan istri patut dinyatakan telah

16 Prasetyawati, N., \& Hanoraga, T. (2015). Jaminan Kebendaan Dan Jaminan Perorangan Sebagai Upaya Perlindungan Hukum Bagi Pemilik Piutang. Jurnal Sosial Humaniora, 8(1), 120-134. h. 121

17 Ibid, h. 130

18 Ibid, h. 125 
melanggar prinsip kehati-hatian. Bahwa faktanya nilai kredit yang disepakati oleh Bank selaku kreditur dengan mantan suami nyata-nyata melebihi plafon kredit yang ditetapkan oleh Bank Indonesia, yang berakibat macetnya kredit tersebut dalam tenggang waktu yang sangat singkat. Menimbang bahwa, mantan istri dalam dalil gugatannya menyatakan perbuatan mantan suami dalam menjaminkan obyek sengketa yang merupakan harta bersamanya dengan mantan istri, kepada Bank selaku kreditur dengan tidak telebih dahulu meminta persetujuan mantan istri merupakan perbuatan yang melanggar hukum. Bahwa setelah mencermati bukti yang telah ditunjukkan pada dalam bagian kolom "menyetujui Suami/Istri" terlihat kosong dan tidak ada tanda tangan dari mantan istri selaku pemilik harta bersama dengan mantan suami. Meskipun mantan suami pada saat menjaminkan obyek sengketa kepada Bank selaku kreditur dalam status telah bercerai, namun oleh karena tidak ada satupun fakta bahwa harta bersama telah dibagi dan masih menjadi satu kesatuan utuh obyek sengketa, maka status obyek sengketa yang dijaminkan kepada Bank Danamon selaku kreditur tersebut masih merupakan harta bersama antara mantan istri dengan mantan suami. Hal ini terjadi karena sebelum adanya pembagian terhadap harta bersama (gono gini) maka status kepemilikan obyek sengketa meskipun telah bercerai tetap melekat sebagai harta bersama.

Dengan demikian menimbang, terbukti perbuatan Bank selaku kreditur yang telah memberikan kredit kepada mantan suami tidak didasari oleh prinsip-prinsip kehatihatian sebagaimana ditentukan dalam aturan perbankan. Bank selaku kreditur menyatakan telah melakukan survey, klasifikasi dan verifikasi hak kepemilikan atas obyek sengketa yang akan dijadikan jaminan kredit, namun menurut Majelis Hakim tidak dapat mematahkan dalil gugatan mantan istri. Kalaupun pada saat itu mantan suami tidak menyertakan persetujuan istri, sepatutnya ada bukti perceraian yang diajukan, sehingga dapat diketahui asal-usul obyek sengketa sebelum memberikan persetujuan kredit. Serta, oleh karena penyerahan jaminan berupa obyek sengketa yang masih berstatus sebagai harta bersama terbukti tidak diikuti oleh persetujuan mantan istri, maka Majelis Hakim berpendapat tindakan mantan suami bertentangan dengan Undang-Undang Perkawinan sekaligus membuktikan mantan suami telah melakukan perbuatan melanggar hukum. Hal ini karena, yang menjadi kajian Majelis hakim dalam perkara ini justru adalah tentang proses awal terjadinya perjanjian kredit antara mantan suami dengan Bank selaku kreditur yang ternyata dilandasi oleh perbuatan melawan hukum karena tidak dilengkapi persetujuan mantan istri sebagai salah satu pihak pemilik tanah obyek sengketa yang dijaminkan. Menimbang bahwa, oleh karena dalam proses penjaminan atas obyek sengketa kepada Bank selaku kreditur dengan mantan suami telah terbukti tidak sah menurut hukum maka berakibat pula pada perbuatanperbuatan hukum selanjutnya berkaitan dengan pemilikan dan penguasaan terhadap obyek sengketa. Oleh karena itu patut dan sangat beralasan untuk menyatakan para mantan suami juga telah melakukan perbuatan melanggar hukum. Majelis hakim berpendapat bahwa mantan istri mampu membuktikan dalil gugatannya tentang pokok perkara, sedangkan pihak-pihak tergugat tidak mampu membuktikan dalil sangkalannya. Dan dalam hal ini, kedudukan Bank selaku kreditur adalah salah dan perbuatan melawan huku serta dinyatakan batal demi hukum dan/atau tidak memiliki kekuatan hukum atas Pedanjian Kredit No. 42/715/PK/0407dan juga Perjanjian Perubahan Terhadap Perjanjian Kredit No. 122/15/ADDENDUM/1107 beserta Akte Pemberian Hak Tanggungan (APHT) No. 751/Kbm/XII/2007. 


\section{Kesimpulan}

Harta perkawinan yang diperoleh selama melangsungkan perkawinan merupakan harta bersama. Perlunya persetujuan dari salah satu pihak apabila ingin menggunakan harta bersama, hal tersebut sesuai dengan ketentuan Pasal 36 ayat (1) Undang-Undang Perkawinan. Bank selaku kreditur dalam memberikan kredit harus memperhatikan prinsip kehati-hatian dan berdasarkan prinsip 5C. Akibat hukum dari pembebanan jaminan atas harta bersama yang diperoleh selama melangsungkan perkawinan dengan tanpa adanya persetujuan dari salah satu pihak atas kredit adalah dapat dibatalkannya (voidable/vermetig) perjanjian jaminan tersebut.

\section{Daftar Pustaka / Daftar Referensi}

\section{$\underline{\text { Buku }}$}

Anshary M. (2016). Harta Bersama Perkawinan Dan Permasalahannya. Bandung: CV Mandar Maju.

Diantha, I. M. P. (2016). Metodologi Penelitian Hukum Normatif dalam Justifikasi Teori Hukum. Jakarta: Prenada Media.

Gazali. D. S. \& Usman Rachmadi. (2012). Hukum Perbankan. Jakarta: Sinar Grafika.

Hartanto. J. A. (2015). Hukum Jaminan dan Kepailitan. Surabaya: Laksbang Justitia.

Usanti, Trisadini Prasastinah \& Bakarbessy Leonora. (2014). Hukum Jaminan. Surabaya: Revka Petra Media.

\section{Jurnal}

Danarta, K. S. (2019). Karakteristik Pemasangan Hak Tanggungan Terhadap Harta Perkawinan. Jurnal Media Hukum dan Peradilan, 5(2), 161-174.

Prasetyawati, N., \& Hanoraga, T. (2015). Jaminan Kebendaan Dan Jaminan Perorangan Sebagai Upaya Perlindungan Hukum Bagi Pemilik Piutang. Jurnal Sosial Humaniora, 8(1), 120-134.

Pratama, A. (2018). Implementasi Percampuran Harta Bersama Dan Harta Bawaan Dalam Perkawinan (Studi Kasus Putusan Pengadilan Agama Nomor: 0189/Pdt. g/2017/Pa. Smg). Jurnal Ius Constituendum, 3(1).

Riyanto, F. S. (2019). KEDUDUKAN KREDITUR ATAS OBJEK JAMINAN FIDUSIA YANG BELUM DIBAGI KARENA ADANYA PERCERAIAN. JURNAL RECHTENS, 8(1).

Subagia, N. K. T. F., \& Rudy, D. G. PENGARUH KEPAILITAN TERHADAP HARTA BERSAMA SUAMI ISTRI DITINJAU DARI PERSPEKTIF. Kertha Wicara: Journal Ilmu Hukum.

Sugiswati, B. (2014). Konsepsi Harta Bersama Dari Perspektif Hukum Islam, Kitab Undang-Undang Hukum Perdata Dan Hukum Adat. Perspektif, 19(3), 201-211.

Waha, F. M. (2013). Penyelesaian Sengketa atas Harta Perkawinan setelah Bercerai. Lex et Societatis, 1(1). 
Wijayanti, W. (2016). Kedudukan istri dalam pembagian harta bersama akibat putusnya perkawinan karena perceraian terkait kerahasiaan bank. Jurnal Konstitusi, 10(4), 709-730.

Van Bone, A. (2017). PENYELESAIAN SENGKETA HARTA BERSAMA BERSTATUS AGUNAN DALAM PERKARA PERCERAIAN DI PENGADILAN NEGERI. LEX ADMINISTRATUM, 5(5).

\section{Peraturan Perundang- undangan}

Kitab Undang-Undang Hukum Perdata

Undang-undang Nomor 16 Tahun 2019 Tentang Perubahan Atas Undang- Undang Nomor 1 Tahun 1974 tentang Perkawinan

Undang-Undang Nomor 39 Tahun 1999 tentang Hak Asasi Manusia 